\title{
Communities of Security Practices in the Age of Uncertainty
}

\author{
ALEXANDRA GHECIU* \\ University of Ottawa, Canada
}

\begin{abstract}
This paper examines some of the challenges involved in recent efforts to create a new community of practice that brings together - within the domain of peacebuilding NATO and humanitarian actors. In recognition of the need to promote systematic cooperation between the alliance and the humanitarian community, NATO has launched several initiatives aimed at constructing a domain of shared knowledge and common procedures, and, on this basis, cultivating mutual trust and a sense of membership in the same community between representatives of the alliance and members of the NGO community. While these initiatives have enjoyed a certain degree of success, at the deeper level the process of forging a new community of practice among these actors remains challenging and fraught with tension. This process has been rendered particularly complicated by the fact that some of the new initiatives challenge fundamental assumptions about self-identity and purpose both in NATO and within the humanitarian community. Indeed, efforts to construct a new community of practice in the domain of peacebuilding both reflect and contribute to intense debates and contestations within the Atlantic Alliance as well as among NGOs about their evolving identities and, linked to that, appropriate logics of action in the future.
\end{abstract}

Keywords: communities of practice, NATO, NGOs, peacebuilding

\section{Introduction}

Since the end of the Cold War, NATO - often portrayed as a key institutional expression of the transatlantic security community - has become increasingly involved in practices of intervention and post-conflict reconstruction in regions that stretch from the Balkans to Afghanistan. These practices have involved an explicit attempt to re-articulate NATO's relationships to a wide range of actors and to seek to construct new communities of practice that incorporate some of those actors. According to NATO documents, this is necessary because, in an age marked by fluidity and uncertainty in the security field, NATO may well be called upon to carry out more non-conventional missions in the future, and if/when that happens it will be crucial for the alliance to be able to act in smooth partnership with other actors. From this perspective, in order for that partnership to be effective, it is important to have in place a significant degree of trust, shared knowledge, clear procedures, as well as sufficient experience of working together so that NATO and a

\footnotetext{
*agheciu@uottawa.ca
} 
host of other institutions can adapt rapidly to a complex security environment anywhere in the world.

This paper provides a brief analysis of some of the challenges involved in efforts to create a new community of practice that brings together NATO and humanitarian actors in the domain of peacebuilding.1 As we shall see, while some limited successes have been achieved in this area, at the deeper level the process of forging a stable new community of practice among these actors remains challenging and fraught with tension. This process has been rendered particularly complicated by the fact that some of the new initiatives challenge fundamental assumptions about self-identity and purpose both in NATO and within the humanitarian community.

\section{Redefining NATO after the Cold War}

There is a growing body of literature that explores the ways in which NATO, as a key institution of the Euro-Atlantic security community, has sought to re-define its identity and reinvent its mandate in an effort to demonstrate its relevance in the post-Cold War era. ${ }^{2}$ One of the most interesting aspects of NATO's reinvention process concerns a new focus on practices of peacebuilding, which are ostensibly aimed not simply at stabilizing war-torn regions or countries, but also at turning them into democratic polities. In recent years, the alliance's emphasis on becoming a prominent player in the domain of peacebuilding has entailed systematic efforts to build a new community of practice that would bring together the alliance and at least certain segments of the humanitarian world.

I treat practices, following Adler and Pouliot, as competent performances and socially meaningful patterns of action. A community of practice is "a configuration of a domain of knowledge that constitutes like-mindedness, a community of people that creates 'the social fabric of learning' and a shared practice that embodies the 'knowledge the community develops, shares and maintains." ${ }^{3}$ As scholars who work in this area have repeatedly argued, the activities carried out by communities of practice are grounded in background knowledge: practices rest on a stock of intersubjective background knowledge that is generally speaking practical, oriented towards competency and skill. ${ }^{4}$ While those taken for granted background assumptions enable members of a community to perpetuate a particular set of practices over time, significant change can occur when - usually in response to problems or crises which challenge existing background knowledge - some members of the community begin to push background knowledge into the foreground in

1 The emphasis in this paper is on efforts to create-and challenges of creating - a community that brings together NATO actors and members of the humanitarian community-but this can be seen as part of a broader project of re-articulating the relationships between NATO and a host of other actors involved in the field of security.

2 See for instance Adler 2008, Gheciu 2005; Williams 2009.

3 Adler and Pouliot 2011, 17

4 See in particular Pouliot 2008. 
an effort to examine what they have been doing, and potentially to explore the desirability of engaging in different types of practices. ${ }^{5}$

Security communities, as Adler has pointed out, are but one type of communities of practice. As the institutional expression of the Western security community, NATO has historically been able

to carry out a wide set of practices based on (socially constructed) background knowledge about "the way we do things" given "our" identity. ${ }^{6}$ In part, that knowledge has been grounded in the assumption that NATO had competencies and carried out activities that were clearly differentiated from the activities of other types of institutions present in the field of security. One set of actors widely perceived - both within and outside the Atlantic Alliance - as clearly different in terms of their identity, mandate, and types of practices they routinely performed was the humanitarian community. In IR parlance, the humanitarian community can be conceptualized as the community that has always prioritized human security at the expense of conventional (state-centric) definitions of security embraced by NATO, and historically dominant in the field of international security. As Janice Gross Stein has pointed out, "the modern humanitarian community constituted itself from its earliest days as a 'community of practice"'? That community, currently consisting of "tens of thousands of NGOs and individuals," defines itself around several fundamental principles: "humanity, impartiality, neutrality, independence, voluntary service, unity and universality." 8

\section{Crossing Boundaries in the Changing Domain of Peacebuilding}

The neat distinction between the humanitarian community and the Atlantic Alliance, however, came under severe strain in the 1990s, following a series of transformations in the field of peacebuilding-and particularly the launch of complex peace-enforcement and post-conflict reconstruction missions. ${ }^{9}$ One of the implications of the growing complexity of peacebuilding operations was that actors with different identities and modus operandi were increasingly put in situations in which they were expected to systematically collaborate in the name of ensuring sustainable peacebuilding. ${ }^{10}$

Yet, it soon became clear that such systematic collaboration would be more difficult to achieve than many policy-makers had expected. Consider, for instance, the difficulties that plagued attempts at coordination between NATO and the humanitarian community

5 See especially Stein 2011.

6 I discuss this in Gheciu 2005.

7 Stein 2011, 87.

8 Stein 2011, 92.

9 See Gheciu 2011.

10 See in particular Paris and Sisk 2010. 
in post-conflict reconstruction efforts in Kosovo, following the establishment of the UN Interim Administration Mission in 1999. ${ }^{11}$ NATO's discourse on Kosovo was based on the assumption that, by virtue of a) its unique material (particularly military) capabilities, and b) its knowledge, experience and skills acquired in previous peace-support operations, coupled with the vast knowledge possessed by its members in the area of protecting liberal democracy, NATO was in an uniquely privileged position to assume a key role in peacebuilding operations. ${ }^{12}$ In other words, NATO officials and leaders of key allied states repeatedly invoked the alliance's material as well as cultural-symbolic capital (knowledge and expertise $)^{13}$ in an effort to secure recognition-in the eyes of their own publics, the international community as well as the eyes of Kosovars-of NATO as a competent peacebuilder.

However, NATO's involvement in humanitarian relief and reconstruction activities was greeted by many NGOs with suspicion and, in some cases, even open hostility. According to many of those organizations, the alliance's involvement in direct assistance to civilians in reconstruction activities undermined the NGOs' position, and made it virtually impossible to establish an impartial humanitarian space-which is seen by the NGO community as vital to the effective provision of assistance to civilians. ${ }^{14}$ Under those circumstances, it was not surprising that, despite some instances of successful collaboration between NATO and certain NGO representatives, the goal of systematic collaboration between the alliance and the humanitarian community was not achieved. ${ }^{15}$

The limitations and challenges of NATO - NGO coordination in the Balkans prompted the allies to argue that lessons would be learned, best practices would be developed and collaboration would occur in a smoother fashion in future missions. But did it? Evidence from NATO's largest contemporary mission-in Afghanistan-suggests that, at least in the first years of that operation, coordination and cooperation between NATO and the humanitarian actors was limited and fraught with tension. In many instances, NGO representatives accused the alliance of a lack of willingness to engage in meaningful cooperation with civilian (including non-governmental) actors, and argued that the NATO-led International Security Assistance Force (ISAF) was "trying to take over everything". ${ }^{16}$ In the eyes of many NGOs active in Afghanistan, far from contributing to

11 See, e.g. Minear, van Baarda and Sommers 2000.

12 Author's interview with NATO senior official, Brussels, May 27, 2000.

13 I use these terms in a Bourdieu-an sense, to refer to the military capabilities of the alliance ('material capital') as well as its authority grounded in perceived expertise, specialized skills and experience (cultural-symbolic capital). For a broader discussion see Gheciu 2008.

14 Author's communication with ICRC official, Oxford, September 2003.

15 See Gheciu 2011 and Rollins 2001.

16 Author's interviews with officials from OXFAM and Medicins sans Frontieres, December 1518, 2007, London. See also Fox 2011. 
sustainable peacebuilding ISAF activities often had adverse implications for development and reconstruction activities. ${ }^{17}$

\section{New Questions about Old Assumptions}

The above-mentioned failures or limitations of cooperation, coupled with the critiques articulated by NATO's peacebuilding partners created a credibility problem for the alliance. The difficulty for NATO was that its often-repeated claims that it had the competence to perform peacebuilding operations in the complex, frequently fluid security environment of the 21st century were systematically contested by other participants in post-conflict reconstruction missions. That process of contestation threatened to destabilize NATO's discourse about its ability to reinvent itself in the new century, and thus to make it more challenging for the alliance to secure the political support needed within allied and partner states in order for the alliance to avoid lapsing into irrelevance. To deal with those recurring contestations, allied officials had to shift away from the type of background assumptions that had underpinned peacebuilding practices conducted in the 1990s and early 2000s. They had to engage - and be seen to be engaging - in a more reflective mode, in which questions could be raised about previously taken-for-granted assumptions about the alliance's expertise and skills in the domain of peacebuilding.

In other words, faced with the prospect of possible failure in its peacebuilding efforts, NATO officials started to advocate the creation of a new community of practice, which would bring together allied representatives and humanitarian actors, uniting them around a shared body of knowledge, a sense of trust, and joint everyday practices. The project to establish such a community of practice is grounded in assumptions that complex operations of today and tomorrow-in Afghanistan and elsewhere-require skills/knowledge/expertise that can only be secured through the participation and systematic cooperation of multiple civilian and military actors. It is also grounded in assumptions that, given the fluidity and unpredictability of the security field, much of this cooperation needs to take place with little prior planning. As Paul LaRose-Edwards has pointed out, NATO is developing "more of an understanding of the nature of civilian operations, and an enduring awareness that just-in-time working interactions will remain a consistent reality in crisis response. Success is premised upon key civil-military partners having the right attitudes and sufficiently common business practice to enable just-intime interactions that minimize time requirements for collaboration and maximize the attainment of common objectives."18

17 Author's interviews with representatives of OXFAM, Save the Children and Médecins Sans Frontières, summer 2007, London.

18 Paul LaRose Edwards 2008, 30. This concern was echoed in the author's interviews with three senior NATO officers involved in peacebuilding operations, summer 2011, London. 
In practice, this translated into an effort on the part of NATO to learn from its mistakes. In part, the project of learning new ways of doing things has involved efforts to forge new communities of practice with other actors, including members of the humanitarian community, in order to acquire new competencies from interactions with those actors, and thus respond to crises in a more efficient fashion. The commitment to transcend old ways of doing things, acquire new competencies and create new communities of practice with non-military actors, including NGOs, became particularly important in the strategic review of Afghanistan carried out by the US in 2009. This was reflected in various statements issued by then ISAF commander, Gen. Stanley McChrystal ${ }^{19}$, and by the NATO Secretary General, Anders Fogh Rasmussen. In Rasmussen's words, “NATO's experience over the past years, notably in Afghanistan, underscores that successful crisis management requires a new compact between all the different civilian and military actors..." ${ }^{20}$ Importantly, this has involved the re-articulation of the relationship between NATO and NGOs, so as "to improve the frequency and quality of the dialogue between NATO and the NGOs [...] drawing from our common experience of Afghanistan and of other crisis areas." ${ }^{21}$

\section{Towards a New Community of Practice?}

In an effort to build a new community of practice that includes humanitarian actors, NATO launched several initiatives in the past few years. A full exploration of those initiatives is impossible within this paper's space constraints, but let us briefly examine a few of the recent programmes/projects launched by the alliance.

In recent years, several new programs were launched aimed at changing the ways in which civilians and military personnel preparing for deployment in Afghanistan are educated. Especially interesting is the growing emphasis on educating military and civilian actors (including NGO representatives) together ${ }^{22}$-for instance within the framework of multiple conferences and workshops--in an attempt to socialize them into shared norms and principles of cooperation, building trust prior to deployment, create anew 'common sense' understandings of reality and develop shared practical knowledge about how to operate in Afghanistan. Such practical knowledge is expected to enable military actors and members of the humanitarian community to tackle shared tasks in ways that are well understood by all the actors involved, and following procedures that are -if not uniformat least not mutually incompatible. ${ }^{23}$

19 McChrystal 2009.

20 Rasmussen 2010.

21 Ibid.

22 Author's interview with an ISAF official, September 7, 2011, Ottawa.

23 Author's interviews with two senior NATO officials involved in organizing a conference for NGOs at the NATO HQ in November 2010 (interviews conducted in Brussels, December 12-15, 2011). 
Linked to this, NATO has also implemented a number of structural changes in the name of facilitating the socialization of a range of civilian actors and military personnel into a particular set of norms, principles and procedures of action in peacebuilding activities. For instance, under the umbrella of the Allied Command Transformation (ACT), the Joint Force Training Centre (JFTC) was set up to support training for NATO and Partner forces in an effort to improve joint and combined tactical interoperability, and more broadly to enhance NATO's competence in contemporary operations. Over the past couple of years, the JFTC has placed special emphasis on training together soldiers and civilians prior to their deployment in Afghanistan. To take just one example, in June 2012 more than 550 soldiers and civilians from 22 NATO and Partnership for Peace nations took part in pre-deployment course for the next rotation of the ISAF Regional Command North members. ${ }^{24}$ Via a combination of academic lectures and exercises based on practical working situations, the training was aimed at creating effective teams, whose members knew and trusted one another, who knew how to work together, who had practised communication between different areas of ISAF as well as with non-ISAF actors (including humanitarian organizations), and who-presumably-would be able to support the Regional Commander in the decision-making process and in fulfilling his duties in Afghanistan.

At this stage, the question that arises is: did any of these initiatives and programs make any difference? Of course, these are still early days-not enough time has lapsed since the launch of the new programs to justify a definitive statement regarding their success or lack thereof. Nevertheless, preliminary assessments-primarily based on anecdotal evidence provided by military officers and civilians deployed in Afghanistan-suggest that this type of joint civilian/military training did have an impact in terms of reducing mistrust and facilitating day-to-day interactions across the military/civilian divide.

For instance, the civilian and military 'students' who participated in the JFTC courses, as well as PRT personnel who had the opportunity to interact with those graduates in Afghanistan have indicated that the bonds and shared knowledge acquired in the course of the JFTC training did make a difference in terms of enabling the alumni to gain a more comprehensive understanding of the Afghan environment even prior to their deployment, and making it easier for them to cooperate-on the basis of procedures learned prior to their deployment-- both with other ISAF actors and with non-ISAF individuals and institutions. ${ }^{25}$

Yet, in spite of these achievements, significant problems continue to plague the relationship between NATO and the humanitarian community, especially in Afghanistan. One of the key obstacles seems to be that the effort to (re)construct a community of practice that brings together NATO and NGO actors has destabilized prevailing

24 Interview with NATO officer involved in organizing the June course, July 2, London.

25 Telephone interviews with two senior NATO officers, one NATO civilian official, and two representatives of international NGOs active in Afghanistan, May 2011 and July 2012. 
understandings regarding military and humanitarian identities and proper competencies, and have generated difficult debates on those issues both within the alliance and among humanitarian actors.

Within NATO, doubts continue to be expressed-in private, if not in public-by some allied officials about the wisdom of even trying to construct this new type of community of practices. ${ }^{26}$ These doubts and concerns are linked to broader debates about the extent to which NATO should be doing out-of-area peacebuilding at all. Thus, in spite of NATO's public statements of support for the ISAF mission, among the allies there continue to be difficult questions about the proper future direction of the alliance. ${ }^{27}$ For instance, officials representing some of the newer (ex-communist) allies have repeatedly argued that NATO has already gone too far in the direction of global policing-particularly in a situation in which, as the 2008 war in Georgia and the recent Russian assertiveness demonstrate, "old" types of dangers have not disappeared. Representatives of this school of thought advocate a return to collective defence as the key competence of NATO, and claim that recent efforts to build a new community of practice that includes actors such as NGOs amount to a potentially dangerous turn away from the types of defence practices at which the alliance can excel, and which can truly protect the territories, populations and shared values of the allied states. ${ }^{28}$

Disagreements within NATO over the desirability of forging a closer relationship to NGOs have been paralleled by debates about identity and desirable competencies within the humanitarian community. As Janice Stein has explained, among NGOs a difficult dialogue started in the 1990s and became even more acute in recent years about the extent to which NGOs needed to rethink the meaning of 'doing good.29 As part of a process of rethinking their role and their competencies, some NGOs have started to work more closely with military actors like NATO. In Afghanistan, for instance, many NGOs-including a series of Afghan NGOs that provide crucial medical and educational services to poor Afghanshave come to work systematically with the alliance, and depend heavily on the funding provided by foreign donors and often channelled directly through PRTs. ${ }^{30}$ By contrast, other NGOs insist that they can only perform their proper roles and remain true to their humanitarian identity if they maintain a clear distance from NATO. ${ }^{31}$

In conclusion: although it is still too early to seek a definitive assessment of the impact of recent NATO initiatives, preliminary evidence suggests that, despite some successes, the

26 Interviews with NATO officers involved in peacebuilding operations, London, Brussels, and Ottawa, 2009-2011.

27 I discuss this, most recently, in Gheciu 2012.

28 Author's interview with senior officials from Poland and the Baltic states, summer 2011, London and Ottawa.

29 Stein 2011.

30 Ibid.

31 Médecins Sans Frontières 2011, 14. 
project of constructing a new community of practice that includes humanitarian actors remains more challenging than official statements of the alliance would suggest. To a significant extent, difficulties in this area stem from the fact that community-building practices have triggered difficult debates and contestations regarding identity and suitable competencies both within the alliance and in the humanitarian community. This is not necessarily to say that the project is inherently doomed. From the point of view of NATO, if the allies decide that they do wish to be able to carry out complex peacebuilding missions in the future, they will likely have little choice but to continue efforts to build new communities of practice that transcend old institutional boundaries. But the evidence that we have so far suggests that if the alliance decides to pursue this goal it will need to go further than it has gone so far in questioning its background knowledge and established procedures, and in learning new ways of doing things. More broadly, there needs to be a recognition that community-building initiatives that aim to bring together NATO and NGO actors need to be addressed in the context of larger efforts to address fundamental questions about identity(and competencies associated with those identities), appropriate institutional roles and logics of action in the twenty-first century. 


\section{References}

Adler, Emanuel. 2008.“The Spread of Security Communities: Communities of Practice, Self-Restraint, and NATO's Post-Cold War Transformation." European Journal of International Relations 14(2): 195-230.

Adler, Emanuel and Vincent Pouliot, eds. 2011. International Practices. Cambridge: Cambridge University Press.

Fox, Edward. 2011."Preparing Civilians for Deployment to Civilian-Military Platforms in Combat Environments: The Evolution of Staffing and Training for the Civilian Mission in Afghanistan." In Towards a Comprehensive Approach: Strategic and Operational Challenges, edited by Christopher Schnaubelt. NATO Defence College Forum Paper no.18.

Gheciu, Alexandra. 2005.NATO in the 'New Europe'. Palo Alto: Stanford University Press.

Gheciu, Alexandra. 2008. Securing Civilization? Oxford: Oxford University Press.

Gheciu, Alexandra. 2011."Divided Partners: The Challenges of Civil-Military Cooperation in Peacebuilding Operations." Global Governance15 (1): 95-114.

Gheciu, Alexandra.2012. "In Search of 'Smart Defence'” CIPS Policy Brief, University of Ottawa.

Gross Stein, Janice. 2011. "Background knowledge in the foreground: conversations about competent practice in 'sacred space." In International Practices, edited by Emanuel Adler and Vincent Pouliot. Cambridge: Cambridge University Press.

LaRose-Edwards, Paul. 2008."NATO and Militaries as Trusted Partners in CivilMilitary Interaction." The Pearson Papers 11 (1): 22-43.

McChrystal, Stanley. 2009. Initial United States Forces-Afghanistan (USFOR-A) Assessment. Memo to Secretary Gates.

Médecins Sans Frontières. 2011. Humanitarian Action: At Any Price? Paris: Annual Report.

Minear, Larry, Ted van Baarda and Marc Sommers. 2000،"NATO and Humanitarian Action in the Kosovo Crisis."Occasional Paper, Watson Institute for International Studies, Brown University. 
Paris, Roland and Timothy D. Sisk, eds. 2009. The Dilemmas of Statebuilding: Confronting the Contradictions of Postwar Peace Operations. London: Routledge.

Pouliot, Vincent.2008. "The Logic of Practicality: A Theory of Practice of Security Communities." International Organization 62: 257-288.

Rasmussen, Anders Fogh. 2010." NATO and NGOs."In Voltaire Network, available at: www.voltairenet.org/a164724

Rollins, John W. 2001.“Civil-Military Cooperation (CIMIC) in Crisis Response Operations: The Implications for NATO."International Peacekeeping8 (1): 122-129.

William, Michael J. 2009. NATO, Security and Risk Management: From Kosovo to Kandahar. London and New York: Routledge. 
